\title{
Plastibell Circumcision Method vs Conventional Circumcision Method in Terms of Operative Outcomes in Paediatric Patients- A Retrospective Study
}

\begin{abstract}
Introduction: Circumcision is most often an elective surgery performed on babies and children, for religious or cultural reasons. In other cases, it may be done as a treatment for certain medical conditions or for preventive reasons. Circumcision is done in cases of phimosis, balanoposthitis and chronic Urinary Tract Infections (UTIs). Various techniques are available for circumcision (Plastibell, Gomco clamp, Mogen clamp, etc.).). However, the practices and procedures of circumcision and complications of various procedures are not well documented. The conventional or plastibell device method is one of the methods most frequently employed for circumcision.
\end{abstract}

Aim: To compare the outcome of circumcision done by conventional technique against plastibell methods.

Materials and Methods: This was a retrospective observational study conducted from May 2017 to January 2019 in the Department of Surgery at LG Hospital, AMC MET Medical College, Ahmedabad. Study included 60 male patients younger than 10 years that underwent circumcision by either conventional method or plastibell method for various indications. Circumcision done for congenital abnormalities like hypospadias, epispadias, webbed penis etc., deranged coagulation profile i.e., bleeding or clotting disorders were excluded from study. The data of 30 children that underwent circumcision with conventional method (Group A) and 30 children with plastibell method (Group B) was collected. The follow-up data like wound at the operative site or any complaints or complications were also recorded. Paired t-test and Chi-square test were used to compare collected data for significance.

Results: The most common indication for circumcision in this study was phimosis $(n=58,96.67 \%)$. The mean age was $4.80 \pm 2.30$ years ( 0 to 10 years). The mean surgical time was $10.17 \pm 1.82$ minutes with estimated blood loss of $11.70 \pm 2.98 \mathrm{~mL}$ in plastibell method while it was $19.73 \pm 2.39$ minutes and $24.80 \pm 4.01 \mathrm{~mL}$, respectively in conventional method $(p<0.0001)$. The most common complication was localised superficial infection in both groups, two patients $(6.66 \%)$ in plastibell method while one patient (3.33\%) in conventional method. The overall postoperative complication rate was more in plastibell method compared with conventional method $(20 \%$ vs $3.33 \%, p=0.04)$.

Conclusion: It was concluded that plastibell method has surgical advantages in children below 10 years even though higher complication rate compare to conventional method due to negligible chance of serious complications and shorter duration of surgery with less amount intraoperative bleeding compared to conventional method.

\section{INTRODUCTION}

Circumcision is one of the world's most widely performed procedures [1]. Approximately, 37\% to $39 \%$ of males worldwide are circumcised [2]. It is most often practiced between infancy and the early 20's [3].

During circumcision enough shaft skin and inner foreskin is removed to uncover the glans [4]. The procedure is most often an elective surgery performed for religious or cultural reasons [5]. Factors to look for during the process are: asepsis; adequate excision of the outer and inner foreskin; haemostasis; cosmetic appearance [6].

Various techniques are available for circumcision, namely plastibell, Gomco clamp, Mogen clamp, Metal shield, Accu-circ, Alis camp, Ismail clamp, Kirve clamp, Bone cutter method, Conventional (open cut) method etc., [7]. Although many techniques for circumcision have been studied extensively but complications of various procedures are not well documented [8].

Circumcision is done either by free hand method or the devices method; the latter being more commonly used in recent practice [5]. This method is easier for a less skilled medical personnel, requires no stitches but a second visit is must for completion procedure. Circumcision by plastibell needs tight strangulation of the foreskin as it sloughs off by ischaemic necrosis of the foreskin [9]. Circumcision by conventional method is achieved by removing the preputial tissue without damaging glans and frenulum [10]. There are several reports of complications associated with the use of conventional methods of circumcision but recently, minimal invasive surgical devices such as plastibell device have been used to reduce complication, intraoperative bleeding and operative duration $[11,12]$.

The study aimed to compare the outcome of circumcision done by conventional technique against plastibell method and to analyse the operative time, intraoperative blood loss and frequency of postoperative complication.

\section{MATERIALS AND METHODS}

This was a retrospective observational study was conducted in the Department of Surgery at LG hospital; AMC MET Medical College, Ahmedabad. The data belonged to the period from May 2017 to January 2019. The study was carried out after getting approval from the Institutional Ethics Committee of AMC-MET Medical College, Ahmedabad (Receipt No: 73-7279). Informed consent of local language was taken from parents of children. 
Inclusion criteria: Paediatric male patients aged below 10 years who underwent circumcision surgery, either by conventional method or plastibell device method, were included in the study.

Exclusion criteria: Circumcision done on paediatric male patients with congenital abnormalities like hypospadias, epispadias, webbed penis etc., patients with deranged coagulation profile i.e., bleeding or clotting disorders, children with no follow-up or if the medical record file was incomplete were excluded from the study.

The study included 60 infants that underwent circumcision surgery either by conventional method or plastibell device method (30 in each group). The method was chosen according to the parents' wish and consents were taken preoperatively, as per the hospital protocol. Most of the surgeries were performed by trained resident doctors assisted and guided by departmental surgical faculty of hospital.

Under aseptic precautions, local anaesthesia was given in the form of ring block with $0.5 \%$ lignocaine $(1 \mathrm{mg} / \mathrm{kg}$ ) applied to the base of the penis or the procedure was done under short general anaesthesia.

\section{Conventional Method (Group A)}

The conventional technique of circumcision involved putting a dorsal slit by crushing cut method and then excising the skin circumferentially. Dorsal penile artery was tied with absorbable sutures with box type stitch, haemostasis was achieved and the skin edges were approximated using absorbable sutures. In absorbable stitches, mostly rapid vicryl 3.0 was used.

\section{Plastibell Method (Group B)}

The plastibell device is a plastic ring with handle and it has a deep groove running circumferentially. Adhesions present between glans and foreskin were divided with an artery forceps. Then the foreskin was longitudinally cut at 12'o clock; prepuce retracted and glans penis exposed. Sizes between 1.1 and $1.5 \mathrm{~cm}$ were utilised in this study. An appropriate size of plastibell device which snugly fit in twothird of glans penis was selected. Plastibell device was then placed on the glans and the foreskin was brought over it. A linen thread ligature which comes with the device was tied firmly around the foreskin, crushing the skin against the groove in the plastibell. The handle of the ring was broken and the excess skin protruding above the groove was excised. The compression of foreskin against the underlying plastic shield by ligature causes necrosis of the foreskin and the ring falls within 3 to 7 days leaving a circumferential wound that heals within few days [Table/Fig-1,2].

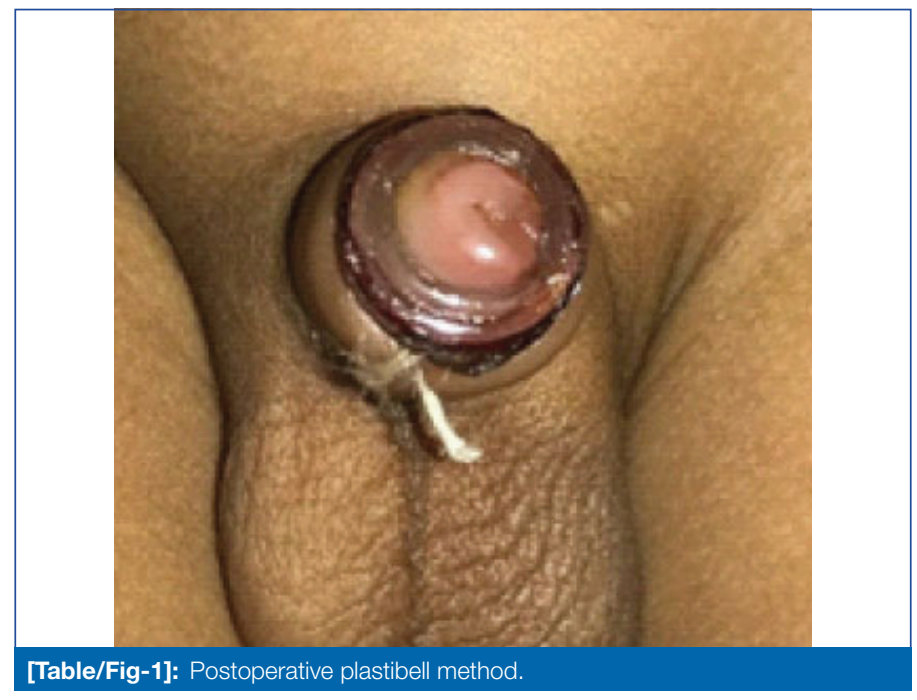

Operative time was calculated in minutes from initiation of surgery after anaesthesia to completion of surgery with dressing. Intraoperative blood loss was calculated by wetting $10 \times 10 \mathrm{~cm}$ gauze with blood. If gauze piece was $25 \%$ soaked with blood, considered as $3 \mathrm{~mL}$ blood loss, if gauze piece was $50 \%$ soaked with blood, considered as $6 \mathrm{~mL}$ blood loss, if gauze piece was 75\% soaked

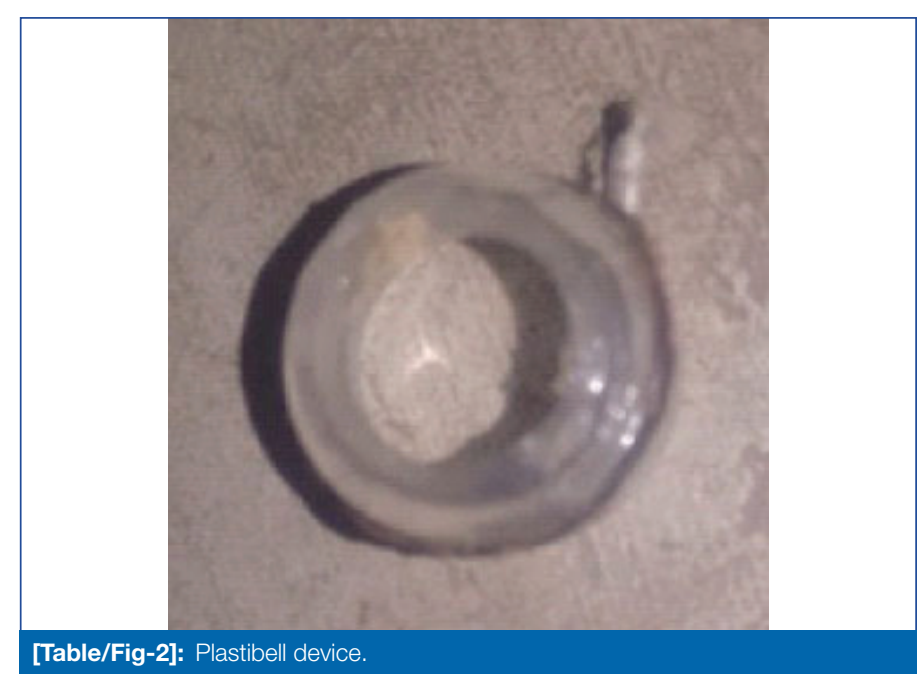

with blood, considered as $9 \mathrm{~mL}$ blood loss and if gauze piece was $100 \%$ soaked with blood, considered as $12 \mathrm{~mL}$ blood loss [13]. In the study hospital, the gauze pieces used during surgeries is counted and recorded pre and postoperatively by scrub nurse.

As per the hospital protocol, the patients were followed-up in Outpatient Department (OPD) bi-weekly. The follow-up data included information like wound at the operative site and complaints or complications were noted. In plastibell method, the follow-up data like day of plastibell separation was also noted. Usually, if the ring was not separated within 12 days, it was removed by cutting the ligature and excising necrotic foreskin.

Data were computed on variables such as age, weight, indication of surgery, operative time of surgery, estimated blood loss during surgery, postoperative complication and postoperative days of separation of plastibell ring.

\section{STATISTICAL ANALYSIS}

All of the statistical analysis was performed using IBM Statistical Package for Social Science (SPSS) software version 22 and MS Office Excel software. Paired t-test was used to compare age and weight distribution, operative time duration and estimate blood loss during surgery between conventional and plastibell method. Chi-square test was used to compare indication of surgery and postoperative complication between conventional and plastibell method. The $p$-value $<0.5$ was considered as significant.

\section{RESULTS}

The mean age of 60 patients was $4.80 \pm 2.30$ years and the mean weight was $15.53 \pm 4.48 \mathrm{~kg}$. The most common indication for circumcision was phimosis ( $n=58 ; 96.67 \%)$. There were 29 cases of phimosis and one for balanoposthitis, in each group [Table/Fig-3].

\begin{tabular}{|c|c|c|c|c|}
\hline Variables & $\begin{array}{l}\text { Conventional } \\
\text { method } \\
(n=30)\end{array}$ & $\begin{array}{l}\text { Plastibell } \\
\text { method } \\
(n=30)\end{array}$ & $\begin{array}{l}\text { Total } \\
(\mathrm{n}=60)\end{array}$ & $\begin{array}{c}\text { Analysis of } \\
p \text {-value }\end{array}$ \\
\hline \multicolumn{5}{|l|}{ Age N (\%) } \\
\hline $0-5$ years & $21(70 \%)$ & 22 (73.33\%) & 43 (71.67\%) & \multirow{3}{*}{$\begin{array}{l}\mathrm{t} \text {-value }=0.11 \\
\mathrm{p} \text {-value: } 0.91\end{array}$} \\
\hline $6-10$ years & $9(30 \%)$ & 8 (26.67\%) & 17 (28.33\%) & \\
\hline Age (Mean \pm SD) & $\begin{array}{c}4.77 \pm 2.40 \\
\text { years }\end{array}$ & $\begin{array}{c}4.83 \pm 2.23 \\
\text { years }\end{array}$ & $\begin{array}{c}4.80 \pm 2.30 \\
\text { years }\end{array}$ & \\
\hline $\begin{array}{l}\text { Weight } \\
\text { (Mean } \pm S D)\end{array}$ & $15.72 \pm 4.59 \mathrm{~kg}$ & $15.34 \pm 4.44 \mathrm{~kg}$ & $\begin{array}{c}15.53 \pm 4.48 \\
\mathrm{~kg}\end{array}$ & $\begin{array}{l}t \text {-value }=0.31 \\
p \text {-value: } 0.75\end{array}$ \\
\hline \multicolumn{5}{|l|}{ Indication } \\
\hline Phimosis & 29 (96.67\%) & 29 (96.67\%) & 58 (96.67\%) & \multirow{2}{*}{$\begin{array}{c}\text { Chi-square: } \\
103.68 \\
\text { p-value } \\
<0.0001\end{array}$} \\
\hline Balanoposthitis & 1 (3.33\%) & 1 (3.33\%) & 2 (3.33\%) & \\
\hline Total & 30 (100\%) & 30 (100\%) & 60 (100\%) & \\
\hline
\end{tabular}

[Table/Fig-3]: Demographic profile of study subjectes.

*The $p$-value $<0.5$ was considered as significant 
Mean operative time duration was $10.17 \pm 1.82$ min and $19.73 \pm 2.39$ min in plastibell method and conventional method, respectively. Meanblood loss was significantly less in the plastibell method [Table/Fig-4].

\begin{tabular}{|l|c|c|c|}
\hline Variables measured & $\begin{array}{c}\text { Conventional } \\
\text { method }(\mathrm{n}=30) \\
(\text { Group } \mathrm{A})\end{array}$ & $\begin{array}{c}\text { Plastibell } \\
\text { method }(\mathrm{n}=30) \\
(\text { Group B) }\end{array}$ & $\begin{array}{c}\text { Paired t-test and } \\
\mathrm{p} \text {-value }\end{array}$ \\
\hline $\begin{array}{l}\text { Time duration of } \\
\text { surgery (min) }\end{array}$ & $19.73 \pm 2.39 \mathrm{~min}$ & $\begin{array}{c}10.17 \pm 1.82 \\
\mathrm{~min}\end{array}$ & $\begin{array}{c}\mathrm{t} \text { value: } 17.01 \\
\mathrm{p} \text {-value }<0.0001\end{array}$ \\
\hline $\begin{array}{l}\text { Estimate blood loss } \\
\text { during surgery (mL) }\end{array}$ & $24.80 \pm 4.01 \mathrm{~mL}$ & $\begin{array}{c}11.70 \pm 2.98 \\
\mathrm{~mL}\end{array}$ & $\begin{array}{c}\mathrm{t} \text { value: } 13.97 \\
\mathrm{p} \text {-value }<0.0001\end{array}$ \\
\hline
\end{tabular}

Out of the total 60 cases, a successful rate of circumcision without any complication was recorded in 53 (88.33\%). Most of complications were managed conservatively. One (3.33\%) patient had postoperative bleeding after plastibell circumcision due to partial dislodgment of the ring; which was corrected by revision of the procedure. Because of usage of inappropriate size of plastibell device, 1 (3.33\%) case of redundant mucosa (glans was poorly exposed due to mucosa) was recorded in plastibell method. In plastibell method, most common complication was delayed separation ring which was occurred in 2 (6.66\%) patients. In those patients, the ring was separated by cutting the ligature and excising necrotic foreskin in follow-up OPD after 12 days [Table/Fig-5].

\begin{tabular}{|c|c|c|c|c|}
\hline \multirow[b]{2}{*}{ Complications } & \multicolumn{2}{|c|}{ Total no. of patients } & \multirow[b]{2}{*}{ Total } & \multirow[b]{2}{*}{ Percentage } \\
\hline & $\begin{array}{c}\text { Conventional } \\
\text { (Group A) }\end{array}$ & $\begin{array}{l}\text { Plastibell } \\
\text { (Group B) }\end{array}$ & & \\
\hline Postoperative bleeding & $0(0 \%)$ & $1(3.33 \%)$ & 1 & $1.67 \%$ \\
\hline Localised superficial infection & $1(3.33 \%)$ & $2(6.66 \%)$ & 3 & $5 \%$ \\
\hline Redundant mucosa & $0(0 \%)$ & $1(3.33 \%)$ & 1 & $1.67 \%$ \\
\hline Delayed separation of the ring & - & $2(6.66 \%)$ & 2 & $3.33 \%$ \\
\hline \multirow[t]{2}{*}{ Total } & $1(3.33 \%)$ & $6(20 \%)$ & 7 & $11.67 \%$ \\
\hline & \multicolumn{2}{|c|}{$\begin{array}{c}\text { Chi-square: } 3.98 \\
\text { p-value: } 0.04\end{array}$} & & \\
\hline
\end{tabular}

The mean number of days for plastibell to separate was $5.18 \pm 1.85$ days for all children who underwent plastibell method; plastibell ring separation was earlier in early $(0-5$ years $)$ age groups $(p<0.0001)$ [Table/Fig-6].

\begin{tabular}{l|c|c|}
\hline Age & Mean days of separation of ring & Paired t-test and $p$-value \\
\hline $0-5$ years & $4.41 \pm 0.96$ days & \multirow{2}{t}{$\begin{array}{c}\text { t-value: } 7.08 \\
\text {-value }<0.0001\end{array}$} \\
\hline $6-10$ years & $8.00 \pm 1.55$ days & -- \\
\hline Total & $5.18 \pm 1.85$ days & \\
\hline \\
[Table/Fig-6]: Separation of plastibell ring. \\
*The $p$-value $<0.5$ was considered as significant
\end{tabular}

\section{DISCUSSION}

The ultimate aim of any method of circumcision is that it should be easy to learn, secure and free from complications. The rate of procedure related complications during and after circumcision is approximately 2 to 6 per $1000[14,15]$. This rate increases 20 -fold for boys who are circumcised between one and nine years of age [16].

Plastibell method is the most common and simple method used for neonatal circumcision around world [17]. In the study by Lazarus J et al., they suggested that plastibell method is an easy to learn method and complications including haemorrhage, local infection, sepsis, maetal stenosis are rare [18] whereas, disastrous complications such as traumatic amputation of glands and urethra cutaneous fistula in conventional method have been noticed by Essid A et al., and Yilmaz AF et al., [19,20]. In this study, such tragic complications were not found in any of the group.
According to Mousavi SA and Salehifar E, out of 205 cases of conventional surgery, 4 (1.95\%) had complications, whereas out of 381 cases of plastibell surgery, $27(7.08 \%)$ had complications [8]. In the study by Moinuddin M et al., a total of 65 (20.96\%) cases out of 310 in plastibell group and 20 (8\%) cases out of 250 in conventional group developed complications [21]. In this study, the overall complication was less in conventional method compared to plastibell method (3.33\% vs 20\%). However, all complications were minor and easily manageable.

The most common complication in plastibell method was superficial infection (6.66\%) and delayed separation of ring (6.66\%). Superficial infection was mostly probably due to inflammatory effect of ligation. The separation ring was faster in younger children aged less than $\leq$ 5 years with $p$-value $<0.0001$. Younger children have a thin prepuce which helps in an early necrosis and sloughing. Mousavi SA and Salehifar E, found that, most common complication was delayed separation of ring (2.6\%) and infection that occurred in 1\% cases which was almost similar to this study [8]; however in Moinuddin M et al., found that the most common complication was postoperative bleeding (8.06\%) followed by localised superficial infection $(5.16 \%)$ and delayed separation of ring (3.54\%) [21].

Because of usage of inappropriately sized plastibell device, a single case of redundant mucosa was recorded in plastibell method. A plastibell device may not have been perfectly secured with a circumferential ligature and partial dislodgment of the ring occurred that leads to postoperative bleeding, which was corrected by revision of plastibell. Hence, choosing correct size of plastibell and close attention to ensure a tight ligature is important in order to prevent complication and need of revision of surgery. Three cases $(1.07 \%)$ of redundant mucosa in plastibell method were recorded in the study by Moinuddin M, due to inappropriately sized bell [21].

A single case of localised superficial infection was the only complication in conventional method which may be due to severe balanoposthitis at presentation. No patient reported with postoperative bleeding in the conventional method group as box stitch was used for dorsal penile artery tying which achieved good haemostasis. This process is time consuming which is the reason for the longer operative time in this group. Plastibell method had the shorter surgery time with less blood loss compared to conventional method ( $p$-value $<0.0001)$. Mousavi SA and Salehifar E, also reported a lesser surgical time in plastibell (3.4 minutes) than conventional method (9.2 minutes) [8]. In the study by Wang $J$ et al., the mean blood loss while using plastibell device was $13.1 \pm 6.1 \mathrm{~mL}$ [22]. In this method, intraoperative bleeding could be prevented by physically occluding blood vessels between device rings but in conventional method, the superficial vein of penis need to be directly ligated and haemostasis was achieved with sutures. This causes a relatively large amount of intraoperative bleeding compared to plastibell method.

Circumcision always should be done by trained personnel. A surgeon should have thorough knowledge of anatomy and be trained in the conventional method of circumcision. So, a major disadvantage of conventional method is long learning curve and operative period compared to plastibell method. It is fraught with more complications in the hands of non experts using conventional circumcision method. The methods of circumcision using plastibell are meant to avoid glans and urethra injury.

\section{Limitation(s)}

Sample size was limited and retrospective data was collected from a single center. So, larger randomised case control studies are required to establish advantages of both methods.

\section{CONCLUSION(S)}

Plastibell circumcision method has an obvious advantage of shorter duration of surgery and less amount of intraoperative bleeding compared to the conventional circumcision method. But, the study 
found that the rate of overall postoperative complications in conventional method was less than plastibell method; however no serious complications were encountered with either.

\section{REFERENCES}

[1] Doyle D. Ritual male circumcision: A brief history. The Journal of the Royal College of Physicians of Edinburgh. 2005;35(3):279-85.

[2] Morris BJ, Wamai RG, Henebeng EB, Tobian AA, Klausner JD, Baneriee J, et al. Estimation of country-specific and global prevalence of male circumcision. Popul Health Metr. 2016;14:4. Doi: 10.1186/s12963-016-0073-5. Erratum in: Popul Health Metr. 2016;14:11. PMID: 26933388; PMCID: PMC4772313.

[3] "Male circumcision: Global trends and determinants of prevalence, safety and acceptability" (PDF). World Health Organization. 2007. Archived (PDF) from the original on 2015-12-22.

[4] Al-Samarrai AY, Mofti AB, Crankson SJ, Jawad A, Haque K, al-Meshari A. A review of a Plastibell device in neonatal circumcision in 2,000 instances. Surg Gyneco Obstet. 1988;167(4):341-43.

[5] Kaplan GW. Complications of circumcision. Urol Clin North Am. 1983;10(3):543-49.

[6] WHO/UNAIDS. Male circumcision: Global trends and determinants of prevalence, safety and acceptability. Geneva: World Health Organization, 2008.

[7] Hammed A, Helal AA, Badway R, Goda SH, Yehya A, Razik MA, et al. Ten years' experience with a novel modification of plastibell circumcision. Afr J Paediatr Surg. 2014;11(2):179-83

[8] Mousavi SA, Salehifar E. Circumcision complications associated with the Plastibell device and conventional dissection surgery: A trial of 586 infants of ages up to 12 months. Adv Urol. 2008;2008:606123.

[9] Jan IA. Circumcision in babies and children with plastibelll technique: An easy procedure with minimal complications-experience of 316 cases. Pak J Med Sci. 2004;20(3):175-80.

[10] Basar H, Yilmaz E, Basar MM. Window technique on circumcision. Int Urol Nephrol. 2006;38:599-601.
[11] Holman JR, Lewis EL, Ringler RL. Neonatal circumcision techniques. Am Fam Physician. 1995;52(2):511-18

[12] Schmitz RF, Schulpen TW, Redjopawiro M. Religious circumcision under local anaesthesia with a new disposable clamp. BJU Int. 201;88:581-85. PMID: 11678755.

[13] Ali Algadiem E, Aleisa AA, Alsubaie HI, Buhlaigah NR, Algadeeb JB, Alsneini HA Bloodlossestimationusing gauzevisualanalogue. TrumaMon. 2016;21(2):e34131. Doi: 10.5812/traumamon-34131. PMID:27626017:PMCID:PMC5003499.

[14] Wiswell TE, Geschke DW. Risks from circumcision during the first month of life compared with those for uncircumcised boys. Pediatrics. 1989;83(6):1011-15.

[15] Srinivasan M, Hamvas C, Coplen D. Rates of complications after newborn circumcision in a well-baby nursery, special care nursery and neonatal intensive care unit. Clin Pediatr (Phila). 2015;54:1185. Doi: 10.1177/0009922 815573932.

[16] El Bcheraoui C, Zhang X, Cooper D. Rates of adrevse events associated with male circumcision in U.S. medical settings, 2001 to 2010. JAMA Pediatr. 2014;168(7):625-34

[17] Yegane RA, Kheirollahi AR, Salehi NA, Bashashati M, Khoshdel JA, Ahmadi M. Late complications of circumcision in Iran. Pediatric Surgery International. 2006;22(5):442-45.

[18] Lazarus J, Alexander A, Rode H. Circumcision complications associated with plastibell device. South African Medical Journal. 2007;97(3):192.

[19] Essid A, Hamzaoui M, Sahil S, Houissa T. Glans reimplantation after circumcision accident. Prog Urol. 2005;15(4):745-47.

[20] Yilmaz AF, Sarikaya S, Yildiz S, Buyukalpelli R. Rare complication of circumcision: penile amputation and reattachment. Eur Urol. 1993;23(3):423-24.

[21] Moinuddin M, Shinde $N$, Devani $R$, Ahmed A. Comparison of plastibell circumcision with conventional circumcision in infants at tertiary care centre. Asian Journal of Research in Surgery AJRS. 2018;1(2):01-07.

[22] Wang J, Zhou Y, Xia S, Zhu Z, Jia L, Liu Y, et al. Safety and efficacy of a novel disposable circumcision device: a pilot randomized controlled clinical trial at 2 centres. Med Sci Monit. 2014;20:454-62. Doi: 1012659/MSM.889722.

\section{PARTICULARS OF CONTRIBUTORS:}

1. Assistant Professor, Department of General Surgery, AMC MET Medical College, Ahmedabad, Gujarat, India

2. Assistant Professor, Department of General Surgery, AMC MET Medical College, Ahmedabad, Gujarat, India.

3. Associate Professor, Department of General Surgery, AMC MET Medical College, Ahmedabad, Gujarat, India.

NAME, ADDRESS, E-MAIL ID OF THE CORRESPONDING AUTHOR:

Jaimin Dipakbhai Shah,

13, Vrundavan Apt, Shantinagar, Usmanpura, Ahmedabad-380013, Gujarat, India

E-mail: jaiminshah0207@gmail.com
PLAGIARISM CHECKING METHODS: [Jain Het al.]

- Plagiarism X-checker: Sep 09, 2020

- Manual Googling: Jan 30, 2021

- iThenticate Software: Mar 08, 2021 (10\%)
ETYMOLOGY: Author Origin

\section{AUTHOR DECLARATION:}

- Financial or Other Competing Interests: None

- Was Ethics Committee Approval obtained for this study? Yes

- Was informed consent obtained from the subjects involved in the study? Yes (from parents)

- For any images presented appropriate consent has been obtained from the subjects. Yes (from parents)
Date of Submission: Sep 04, 2020

Date of Peer Review: Sep 30, 2020

Date of Acceptance: Feb 06, 2021

Date of Publishing: Jul 01, 2021 